\title{
SPRAWOZDANIE Z MIĘDZYNARODOWEJ KONFERENCJI NAUKOWEJ IMAGE OF MAN IN SOCIAL SCIENCES, TRNAVSKÁ UNIVERZITA V TRNAVE, TRNAWA, 30 MARCA 2017 R.
}

30 marca 2017 roku na Uniwersytecie Trnawskim w Trnawie na Słowacji miała miejsce międzynarodowa konferencja naukowa nt. Obraz cztowieka w naukach spotecznych. Sympozjum zostało zorganizowane przez Sekcję Etyki i Filozofii Moralnej Wydziału Filozoficznego Uniwersytetu Trnawskiego oraz Sekcję Etyki Wydziału Filozofii Chrześcijańskiej Uniwersytetu Kardynała Stefana Wyszyńskiego w Warszawie. W spotkaniu wzięli udział przedstawiciele kilku środowisk naukowych z Czech, Polski i Słowacji.

Konferencja stanowiła jeden $z$ etapów realizacji międzynarodowego projektu badawczego VEGA nr 1/0375/16 nt. Idea of Man between Profanum and Sacrum in Russian Thinking of $20^{\text {th }}$ Century. Kierownikiem tego projektu, realizowanego w latach 2016-2018, jest dr hab. Jaromir Feber - pracownik naukowo-dydaktyczny Uniwersytetu Trnawskiego oraz Uniwersytetu Technicznego w Ostrawie w Czechach, natomiast do grupy wykonawców należą m.in. ks. prof. dr hab. Ryszard Moń oraz ks. dr hab. Andrzej Kobyliński z Instytutu Filozofii Uniwersytetu Kardynała Stefana Wyszyńskiego w Warszawie.

Uczestników sympozjum powitała prof. dr hab. Helena Hrehová, kierownik Katedry Etyki i Filozofii Moralnej Wydziału Filozoficznego Uniwersytetu Trnawskiego. Zwróciła ona uwagę na obchodzony w 2017 roku jubileusz 25-lecia tej uczelni. Obecnie funkcjonujaccy Uniwersytet Trnawski w Trnawie został utworzony 25 marca 1992 roku, ale nawiązuje swymi korzeniami i nazwą do dawnego Uniwersytetu 
Trnawskiego, założonego 12 maja 1635 roku przez Petera Pázmana, arcybiskupa Ostrzyhomia (Esztergom) - węgierskiego miasta nad Dunajem.

Otwarcia konferencji dokonał prof. dr hab. Milan Katuninec, dziekan Wydziału Filozoficznego Uniwersytetu Trnawskiego. Mówca przypomniał niezwykle bogatą i długą historię tego ateneum. Prof. Katuninec stwierdził, że filozofia ma dzisiaj do odegrania ważną rolę w kształtowaniu postawy wzajemnego szacunku między ludźmi oraz w promowaniu ideałów wolności i sprawiedliwości. Także w demokracji potrzebna jest rzetelna wiedza filozoficzna i humanistyczna, która może pomóc ludziom w tym, jak nie stać się ofiarą wielu nowych form manipulacji i zniewolenia. Poważnym wyzwaniem w krajach demokratycznych stają się dzisiaj postawy społeczne nacechowane agresją, nienawiścią i przemocą. W zwalczaniu tego rodzaju patologii bardzo potrzeba odpowiedniej wiedzy antropologicznej i etycznej, która zwraca uwagę na kategorię godności osoby ludzkiej i pomaga w adekwatnej diagnozie współczesnej kultury transmodernistycznej.

Sesji przedpołudniowej przewodniczyła dr hab. Alžbeta Dufferová z Uniwersytetu Trnawskiego. Pierwszy referat nt. Obraz cztowieka w kulturze medialnej wygłosiła prof. dr hab. Božidara Turzonovová - rektor Akademii Mediów (Akadémia médii) w Bratysławie, uczelni założonej w 2006 roku przez Stowarzyszenie Dziennikarzy Słowackich. Pani Rektor ukazała w swoim wystąpieniu to, co odróżnia człowieka nowożytnego od ludzi czasów antycznych. Jej zdaniem bardzo trafnie opisał tę różnicę Martin Heidegger, który twierdził, że w nowożytności świat stał się naszym obrazem. Człowiek nowożytny jest podmiotem, na którym opiera się wszelki byt. W konsekwencji cały świat staje się obrazem. Tam, gdzie świat czyni się obrazem, byt w całości zakłada się jako coś, na co człowiek się nastawia i co chce zatem pozwać przed siebie, mieć przed sobą. Światoobraz w tym rozumieniu nie oznacza więc obrazu świata, lecz świat pojmowany jako obraz. Kategoria światoobrazu jest bardzo ważna dla interpretacji współczesnych form rzeczywistości wirtualnych, w których wielu 
ludzi tworzy swoje ,ja” idealne, często całkowicie odmienne od ,ja” zamieszkującego świat rzeczywisty.

Drugim referatem w sesji przedpołudniowej było wystąpienie ks. prof. dr. hab. Ryszarda Monia nt. Rola i zadania etyka w ksztattowaniu spoteczenstwa obywatelskiego. Na czym polega etyczność etyki? Jak należy wykładać etykę, aby było to właściwe $\mathrm{z}$ moralnego punktu widzenia i służyło kształtowaniu społeczeństwa obywatelskiego? Mówca stwierdził, że odpowiedzi na tak postawione pytania należy szukać m.in. w jednym $\mathrm{z}$ artykułów ks. prof. Tadeusza Stycznia (1931-2010) pt. Objawić osobę. W artykule jest zawarte przekonanie autora, że etycy powinni głosić przede wszystkim orędzie godności osoby. Czy jest to w ogóle możliwe? Jak to robić godziwie, by nie manipulować tymi, do których się zwracamy?

Styczeń często powtarzał, że osoba jest kimś jedynym i niepowtarzalnym. W człowieku jako osobie istnieje relacja wewnątrzosobowa - relacja między mną jako podmiotem a mną jako przedmiotem. Etyk ma pomagać w budowaniu takiej relacji. Dlaczego? Aby osoba uznała zarówno godność własnej osoby, jak i drugiego człowieka jako osoby. Styczeń utrzymywał, że objawianie godności człowieka jako osoby może dokonać się jedynie przez wspólne poszukiwanie prawdy, co wydaje się być szczególnie ważne w czasach tworzenia społeczeństwa obywatelskiego. W nauczaniu etyki wielką rolę do odegrania ma literatura, szczególnie poezja. Mówiąc o objawianiu osoby osobie, a tym samym pokazując, jak etycznie nauczać etyki, warto zwrócić uwagę i na to, że Tadeusz Styczeń uważał, iż nie da się jej ukazać jedynie na płaszczyźnie filozoficznej. Utrzymywał, że trzeba jeszcze odwołać się do tego, co na temat godności człowieka mówi Objawienie, gdyż ukazuje ono najpełniej wielkość i niepowtarzalność osoby ludzkiej.

Warto w tym miejscu dodać, że ks. prof. Ryszard Moń był członkiem rady naukowej omawianej konferencji. 29 marca 2017 roku wziął także udział w posiedzeniu Rady Wydziału Filozoficznego Uniwersytetu Trnawskiego, które było poświęcone postępowaniu 
awansowemu o nadanie tytułu profesora dr. hab. Jaromirowi Feberowi. Prof. Moń był członkiem siedmioosobowej komisji, która $\mathrm{w}$ słowackim systemie procedowania w postępowaniu o nadanie tytułu profesora ma kluczowe znaczenie, a zwieńczeniem tej procedury jest nadanie tytułu profesora przez prezydenta Republiki Słowackiej.

Kolejnym wystąpieniem w tej części obrad był referat prof. dr. hab. Heleny Hrehovej nt. Cztowiek w filozofii spotecznej Mikotaja Bierdiajewa i Jacquesa Maritaina a wspótczesna koncepcja wielokulturowości wedtug Briana Faya. Mówczyni z Trnawy stwierdziła, że Bierdiajew i Maritain opowiadali się za integralnym poznaniem bytu ludzkiego. Zdaniem tych dwóch ważnych filozofów chrześcijańskich filozofia społeczna powinna być zbudowana na adekwatnej antropologii. Tylko na gruncie odpowiedniej koncepcji osoby należy szukać możliwości kształtowania dialogu społecznego, tworzenia więzi międzyludzkich i przezwyciężania wszelkich form dehumanizacji bytu ludzkiego. Diagnozy wypracowane przez Bierdiajewa i Maritaina należy dzisiaj połączyć z podejściem wielokulturowym w naukach społecznych, o którym mówi m.in. amerykański filozof Brian Fay w swojej książce z 1996 roku pt. Contemporary Philosophy of Social Science: A Multicultural Approach.

Czwartym wystąpieniem w sesji przedpołudniowej był referat nt. Postkomunizm, liberalizm i solidarnoś́ w krajach Europy Środkowej $i$ Wschodniej po 1989 roku, wygłoszony przez ks. dr. hab. Andrzeja Kobylińskiego. Prelegent zauważył, że w 2017 roku minęło 100 lat od wybuchu rewolucji lutowej w carskiej Rosji i dokonanego kilka miesięcy później krwawego przewrotu bolszewików, nazywanego najczęściej rewolucją październikową. Niestety, setna rocznica narodzin komunizmu na świecie nie stała się okazją do podjęcia nowych badań naukowych, które pomogłyby lepiej zrozumieć specyfikę i konsekwencje tego barbarzyńskiego systemu zniewolenia milionów ludzi.

Szczególnie zastanawia i zasmuca prawie całkowity brak pogłębionych analiz filozoficznych, antropologicznych czy etycznych, które odsłaniałyby przed nami mroki reżimu komunistycznego i najgłębsze 
korzenie zła tego systemu. Jednym z ważnych obszarów badawczych powinna być transformacja ustrojowa w krajach Bloku Wschodniego po 1989 roku. Niestety, brakuje rzetelnych analiz dotyczących specyfiki przejścia od komunizmu do postkomunizmu, a następnie od postkomunizmu do demokracji liberalnej w poszczególnych krajach. Właściwego opisu wymagają przede wszystkim różne modele postkomunizmu, ukształtowane w poszczególnych państwach tej części Europy, oraz obecna kondycja społeczeństw obywatelskich funkcjonujących w tych krajach. Wydaje się, że w procesie przejścia od postkomunizmu do demokracji liberalnej ma wielką rolę do odegrania kategoria solidarności jako ważna cnota życia społecznego.

Piąty referat w porannej części konferencji wygłosiła dr Katarina Vadiková z Uniwersytetu Trnawskiego nt. Etyka w praktyce pracownika socjalnego: identyfikacja klienta. Mówczyni stwierdziła, że w przygotowaniu pracowników socjalnych wielką rolę do odegrania ma szeroko rozumiana wiedza filozoficzna. Głównym celem pracy socjalnej jest socjalizacja osób objętych różnymi formami pomocy. Ludzie dotknięci biedą, bezrobociem czy wykluczeniem społecznym potrzebują szacunku, wsparcia, zrozumienia. Mówiąc językiem filozoficznym, należy im pomóc w zrywaniu masek i odkrywaniu twarzy. Wiedza filozoficzna jest szczególnie potrzebna w procesie identyfikacji klientów pomocy społecznej. Należy zastosować właściwe metody, aby dobrze diagnozować rzeczywiste potrzeby takich osób oraz skutecznie chronić je przed manipulacją, przemocą i wykorzystaniem.

Kolejnym wystąpieniem w tej części obrad był referat dr. hab. Jaromira Febera nt. Podstawy metodologiczne filozoficznej definicji cztowieka. Prelegent z Czech ukazał w swoim wystąpieniu różne koncepcje poznania w filozofii nominalistycznej i realistycznej. Odrębne koncepcje człowieka, wypracowane na gruncie nominalizmu i realizmu, mają zasadniczy wpływ na różne sposoby rozumienia relacji jednostki do społeczeństwa. W jaki sposób istnieje społeczeństwo? Czym jest substancja społeczna? Jak rozumieć istnienie bytów kolektywnych? 
Tego rodzaju pytania są niezwykle ważne na gruncie filozofii marksistowskiej, która dokonuje absolutyzacji społeczeństwa i głosi prymat kolektywu nad jednostką ludzką.

Ostatni referat w sesji przedpołudniowej wygłosiła dr hab. Alžbeta Dufferová nt. Obraz chrześcijanina w prawostawnej, katolickiej i protestanckiej etyce spotecznej. Mówczyni podkreśliła, że etyce społecznej chodzi o moralną ocenę wymiaru społecznego, a zatem owej instytucjonalnej struktury, w której zagęszczają się i krystalizują wzajemne oddziaływania. Pytanie zasadnicze brzmi: czy funkcjonujące instytucje są sprawiedliwe? Etyka społeczna osądza na podstawie kryteriów moralnych stosunki społeczne, struktury społeczne, władze rządowe i samorządowe itd. Usiłuje poddać krytycznemu badaniu struktury instytucjonalne, a jeśli to konieczne, przedstawiać propozycje ich udoskonalenia. Na gruncie prawosławia, katolicyzmu i protestantyzmu ukształtowały się na przestrzeni dziejów odrębne tradycje etyki społecznej, które dzisiaj powinny współpracować ze sobą m.in. w promowaniu różnych form działalności charytatywnej.

Sesji popołudniowej przewodniczyła dr hab. Eva Orbanová z Uniwersytetu Trnawskiego. Obrady rozpoczęły się od wystąpienia Julii Rejewskiej z UKSW w Warszawie nt. Stosunek do nienarodzonych miara jakości demokracji. Prelegentka przybliżyła w swoim wystąpieniu poglądy Tadeusza Stycznia na temat stosunku władzy państwowej do dzieci nienarodzonych jako ważnego przejawu kondycji moralnej systemu demokratycznego. Zdaniem tego myśliciela ochrona prawa do życia człowieka poczętego jest nierozerwalnie związana z troską o kształt współczesnej demokracji. Niezbywalność praw człowieka wyraża konieczną dla afirmacji osoby ludzkiej ochronę dóbr dla niej istotnych. Wśród tych niezbywalnych praw, których nienaruszalność umożliwia afirmację człowieka, należy wyróżnić prawo do życia. Styczeń twierdził, że stosunek państwa i społeczeństwa do dzieci nienarodzonych jest swoistą miarą demokracji. Prawdziwie demokratyczne są jedynie te państwa, które zauważają związek między obroną życia nienarodzonego a afirmacją człowieka i respektują go. Jedynie 
troska o życie tych, którzy nie mogą upomnieć się o swoje prawa, świadczy o autentycznej wolności każdego człowieka. Respektowanie wolności nadaje demokracji właściwy kształt.

Drugim referatem po przerwie obiadowej było wystąpienie mgr. Macieja Papierskiego z UKSW w Warszawie nt. Fikcja literacka jako wyraz doświadczenia moralnego wedtug Tadeusza Stycznia. Mówca rozpoczął swój referat od przywołania opinii amerykańskiej intelektualistki Marty Nussbaum na temat roli, jaką odgrywa literatura w nauczaniu etyki oraz w interpretacji doświadczenia moralnego. Podobne stanowisko prezentował także ks. prof. Tadeusz Styczeń, który podkreślał wielkie znaczenie dzieł literackich dla rozwoju moralnego człowieka. W tekstach filozoficznych i etycznych tego autora można spotkać bardzo często odwołania do takich wielkich utworów literackich, jak Antygona Sofoklesa, Maty Ksiqż̨ Antoina de Saint Exupery'ego czy Zbrodnia i kara Fiodora Dostojewskiego. Styczeń uważał, że należy przygotowywać podręczniki etyki tak, jak pisał swoje Myśli Blaise Pascal. Poeci, dramaturdzy, literaci pomagają nam w realizacji podstawowego zadania każdej rzetelnej refleksji etycznej: objawienia osoby i jej zaafirmowania. W jednym z artykułów Styczeń cytował rosyjskiego poetę Eugeniusza Jewtuszenkę, który powiedział, że poezja to filozofia życia w koncentracie.

Kolejny referat w tej części obrad wygłosił dr Marian Gliganič z Uniwersytetu Trnawskiego nt. Poza tym, co widzialne. Prelegent przybliżył w swoim wystąpieniu problem ludzi bezdomnych oraz zwrócił uwagę na rolę filozofii w trudnym dziele przywracania takim osobom podmiotowości, szacunku do samych siebie czy poczucia własnej wartości. Obraz samych siebie ludzi bezdomnych bardzo skutecznie poprawia terapia narracyjna, która jest jednym z podejść bazujących na ideach społecznego konstrukcjonizmu. Koncentruje się na znaczeniu, jakie posiada język i kultura w procesie interpretowania wydarzeń. Skupia się również na nadawaniu przez ludzi sensu swoim doświadczeniom. Za twórców tego podejścia uważa się Michaela White’a oraz Davida Epstona, którzy zauważyli związki 
pomiędzy tym, jak dana osoba opisuje siebie i swoje życie, a tym, jak go doświadcza i je rozumie. Proces terapeutyczny w tym ujęciu skupia się na współtworzeniu nowych znaczeń, które pozwolą zmienić istniejącą narrację.

Czwartym wystąpieniem po przerwie obiadowej był referat nt. Obraz cztowieka w brytyjskiej szkole smaku, który wygłosiła mgr Simona Bartíková z Uniwersytetu Trnawskiego. Mówczyni stwierdziła, że jeden $\mathrm{z}$ podstawowych problemów omawianych $\mathrm{w}$ osiemnastowiecznej brytyjskiej estetyce dotyczył sposobu określenia prawideł smaku, kryteriów oceny dzieł przyrody czy też sztuki, które pozwalałyby wyznaczyć jego obiektywną wartość: czy możliwe jest ich określenie a priori, czy też należy oprzeć się na doświadczeniu? Już na początku XVIII wieku odnajdujemy ciekawą propozycję, która jest wyraźną antycypacją rozwiązania zaproponowanego kilkadziesiąt lat później przez Davida Hume’a. Otóż w jednym ze swych artykułów Joseph Addison stwierdził, że sztuki mogą wyprowadzić swe prawa i zasady z powszechnego zmysłu i smaku ogółu ludzi, nie zaś z zasad samych sztuk, a zatem to nie smak musi podporządkować się sztuce, ale sztuka - smakowi.

Kolejny referat w sesji popołudniowej wygłosiła mgr Katarína Vurčíková z Uniwersytetu Trnawskiego nt. Obraz cztowieka w środowisku edukacji szkolnej. Prelegentka podkreśliła w swoim wystąpieniu znaczenie rozwoju moralnego w procesie wychowania dzieci i młodzieży oraz ukazała niezwykle istotną rolę, jaką ma do odegrania etyka w dziele kształtowania wrażliwości moralnej młodego pokolenia. Jednym $z$ najważniejszych wyzwań w tym obszarze jest kształtowanie postaw altruistycznych, przezwyciężanie zachowań egoistycznych, budzenie szacunku dla potrzeb innych ludzi, eliminowanie wszelkich form agresji i przemocy.

Ostatnim wystąpieniem sesji popołudniowej był referat dr. Petera Rusnáka z Uniwersytetu Trnawskiego nt. Jana Patočki obraz cztowieka w filozofii. Mówca stwierdził, że czeski filozof Jan Patočka należy do największych myślicieli XX wieku. Patočka był oddanym 
przyjacielem i ostatnim wielkim uczniem Edmunda Husserla. Studiował także pod kierunkiem Martina Heideggera. Podczas studiów we Fryburgu zapoczątkował długoletnią przyjaźń z asystentem Husserla, Eugenem Finkiem. W filozoficznej analizie bytu ludzkiego Patočka zwrócił szczególną uwagę na egzystencjalne struktury cielesności.

W dyskusji podsumowującej konferencję zwrócono uwagę na wielką tradycję duchową i intelektualną świętych Cyryla i Metodego, którzy przypominają nam dzisiaj o słowiańskiej tożsamości krajów Europy Środkowej i Wschodniej. Narody słowiańskie mają dzisiaj do odegrania ważną rolę na kontynencie europejskim, który podlega obecnie głębokiej transformacji. Należy podkreślać specyfikę naszej części Europy tak w relacji do Rosji, jak i w kontaktach z krajami zachodnimi.

Niestety, bardzo często państwa byłego Bloku Wschodniego są traktowane $\mathrm{w}$ krajach zachodnioeuropejskich oraz na innych kontynentach jako „ziemia nieznana” (terra incognita). Dlatego potrzeba wspólnych projektów badawczych, realizowanych w ramach współpracy naukowej między ośrodkami uniwersyteckimi krajów Europy Środkowo-Wschodniej. Te projekty będą pogłębiać wzajemną integrację i promować wiedzę o naszym regionie. Tego rodzaju inicjatywy badawcze powinny zaowocować publikacjami w języku angielskim, dzięki którym mieszkańcy innych kontynentów będą mogli lepiej poznać tradycje filozoficzne i kulturowe naszej części Europy.

ANDRZEJ KOBYLIŃSKI

a.kobylinski@uksw.edu.pl

Uniwersytet Kardynała Stefana Wyszyńskiego w Warszawie, Instytut Filozofii

Wóycickiego 1/3, 01-938 Warszawa

DOI: 10.21697/spch.2017.53.4.42 